\title{
Pelatihan dan Pengembangan Perangkat Pembelajaran Berdasarkan Permendikbud Nomor 22 Tahun 2016 pada Guru- Guru di Gugus V Kediri, Kecamatan Kediri Kabupaten Tabanan
}

\section{Dewa Nyoman Sudana*}

${ }^{1} J u r u s a n$ Pendidikan Guru Sekolah Dasar Undiksha

\section{A R T I C L E I N F 0}

Article history:

Received 18 Oktober 2017

Received in revised form 14 November 2017

Accepted 17 Januari 2018 Available online 20 Februari 2018

\section{Kata Kunci:}

Pelatihan,

Pengembangan,

Rencana Pelaksanaan

Pembelajaran.

Keywords:

Training,Development, Lesson Plan

\section{A B S T R A K}

Kegiatan ini merupakan kegiatan penganbdian kepada masyarakat dalam bidang pendidikan. Tujuan kegiatan pengabdian kepada masyarakat ini adalah untuk meningkatkan kemampuan guru-guru sekolah dasar Gugus V Kecamatan Kediri Kabupaten Tabanan dalam mengembangkan perangkat pembelajaran berdasarkan Permendikbud Nomor 22 tahun 2016. Kegiatan pengabdian kepada masyarakat ini dilasanakan selama tujuh bulan yang dimulai pada hari Sabtu tanggal 2 April 2017 dengan memberikan pengetahuan tentang pengembangan perangkat pembelajaran, dalam bentuk pelatihan dan pedampingan dengan metode ceramah, tanyajawab, diskusi dan penugas. Untuk mengetahui kemampuan guru dalam membuat rencana pelaksanaan pembelajaran digunakan metode observasi dan penilaian tugas. Hasil obsevasi menunjukan bahwa dari 25 orang guru peserta seluruhnya mengikuti kegiatan dengan antusias dari awal sampai akhir kegiatan. Sedangkan dari penilaian terhadap tugas yang berupa perangkat pembelajaran menunjukkan bahwa 96 persen atau 24 orang sudah memahami serta mampu membuat RPP dengan baik, 4 persen atau 1 orang guru dengan kemampuan baik. Dari hasil yang diperoleh dapat dinyataka bahwa pelaksanaan P2M di Gugus V Kecamatan Kediri, Kabupaten Tabanan terlaksana dengan lancar dan berhasil dengan baik.

\section{A B S T R A C T}

This activity was a community work in education. The purpose of this activity was to improve elementary school teachers' ability in SD Gugus $V$ of Kediri district of Tabanan regency in developing teaching materials based on the Regulation of the Minister of Education and Culture No. 22 of Year 2010. This community work was done in seven months starting from $2^{\text {nd }}$ April, 2017 by giving knowledge about materials development in the form of training and tutoring using lecturing, question and answer, discussion and assignment methods. To know the teachers' ability in writing lesson plans, observation and task assessment methods were used. The results of obserrvation showed that all of the 25 participating teachers were enthusiastic from the beginning to the end of the activity. While from the assessment of the tasks in the form of materials development it was shown that $96 \%$ or 24 teachers understood and were able to write lesson plans well and $4 \%$ or 1

\footnotetext{
* Corresponding author.

E-mail addresses: dewasudana245@yahoo.co.id (Dewa Nyoman Sudana),
} 
person had a good ability. From the results obtained it can be stated that the implementation of P2M in Gugus V, Kediri district, Tabanan regency was done smoothly and successful.

Copyright (C) Universitas Pendidikan Ganesha. All rights reserved.

\section{Pendahuluan}

Masalah pendidikan menjadi perhatian serius bagi setiap Negara didunia. Kualitas pendidikan suatu bangsa sejalan dengan kemajuan suatu bangsa dan Negara. Indonesia sampai saat ini masih ketinggalan kualitas pendidikannya dibandingkan dengan negara-negara maju dan berkembang di dunia. Nilam dalam Astawan, 2015 menyatakan bahwa mutu pendidikan Indonesia lebih rendah dari Negara tetangganya di Asia Tenggara, yaitu Malaysia dan Thailand. Rendahnya kualitas pendidikan Indonesia berimplikasi pada rendahnya pula sumber daya manusia (SDM) yang dimiliki.

Sesungguhnya pemerintah telah menyadari bahwa pendidikan memegang peranan penting dalam membentuk sumber daya manusia yang berkualitas yang sangat diperlukan dalam pembangunan bangsa. Oleh karena itu pemerintah telah berkomitmen untuk meningkat kualitas pendidikan dengan berbagai usaha seperti peningkatan anggaran pendidikan yang diimplementasikan dalam program dana Bantuan Operasional Sekolah (BOS) (Kemendiknas,2010), penyempurnaan kurikulum; dari kurikulum Berbasis Kompetensi (KBK) menjadi Kurikulum Tingkat Satuan Pendidikan (KTSP), dan kini kurikulum 2013. Dengan upaya-upaya yang dilakukan pemerintah tersebut seyogyanya peningkatan mutu pendidikan di Indonesia dapat dicapai secara optimal.

Namun kenyataannya dari hasil-hasil studi menunjukkan mutu pendidikan di Indonesia masih rendah. Laporan monitoring global yang dikeluarkan oleh lembaga PBB, UNESCO, pada tahun 2005 terungkap bahwa mutu pendidikan di Indonesia berada pada peringkat 10 dari 14 negara berkembang di kawasan Asia Pasifik (Muhliz, 2009). Konsorsium Internasional (2010), melaporkan bahwa dalam bidang IPA, Indonesia masuk peringkat 32 dari 36 negara. Indeks pembangunan pendidikan untuk semua menurut UNESCO dalam EFA Global Monitiring Refot 2011, melaporkan bahwa Indonesia menempati 67 dari 127 negara (Kompas, 2011). Hal serupa juga dilaporkan oleh United Nations Development Programme (UNDP), Humen Development Index (HID) yaitu Indonesia berada diperingkat 109 dari 179 negara (UNDP, 2009). Fakta-fakta tersebut memberikan gambaran bahwa mutu pendidikan Indonesia perlu ditingkatakan.

Bercermin dari rendahnya mutu pendidikan di Indonesia, tentu ada permasalahan yang mesti dibenahi. Salah satu permasalahan adalah masalah kualitas pendidik (guru). Guru merupakan ujung tombak didalam meningkatkan mutu pendidikan. Kurikulum yang bagus, sarana dan prasarana yang memadai belum menjadi jaminan dapat meningkatkan mutu pendidikan tanpa didukung oleh guru yang berkualitas. Oleh karena itu peningkatan kualitas guru merupakan suatu keharusan. Salah satu upaya peningkatan kualitas guru adalah melalui kegiatan pengembangan profesi. Pengembangan profesi guru merupakan kegiatan yang dilakukan guru dalam rangka pengamalan ilmu peengetahuan, teknologi, dan keterampilan untuk meningkatkan kualitas guru. Sorang guru berkualitas harus memiliki empat kompetensi. Salah satu kompetensi itu adalah kompetensi profesional. Kompetensi professional meliputi kemampuan dan keterampilan guru merencanakan, melaksanakan dan mengevaluasi serta memberikan tindak lanjut pembelajara.

Dalam Peraturan Menteri Pendidikan Dan kebudayaan No. 22 Tahun 2016 tentang Standar Proses pendidikan dasar dan menengah dinyatakan bahwa pembelajaran diselenggarakan melalui proses interaksi antar peserta didik dan antara peserta didik dengan pendidik dan sumber belajar pada suatu lingkungan belajar. Pembelajaran dilaksanakan berbasis aktivitas dengan karakteristik:

a. interaktif dan inspiratif;

b. menyenangkan, menantang, dan memotivasi peserta didik untuk berpartisipasi aktif;

c. kontekstual dan kolaboratif;

d.memberikan ruang yang cukup bagi prakarsa, kreativitas, dan kemandirian peserta didik; dan e.sesuai dengan bakat, minat, kemampuan, dan perkembangan fisik serta psikologis peserta didik.

Pembelajaran menggunakan pendekatan, strategi, model, dan metode yang mengacu pada karakteristik. Pendekatan pembelajaran merupakan cara pandang pendidik yang digunakan untuk menciptakan lingkungan pembelajaran yang memungkinkan terjadinya proses pembelajaran dan tercapainya kompetensi yang ditentukan. Strategi pembelajaran merupakan langkah-langkah sistematik dan sistemik yang digunakan pendidik untuk menciptakan lingkungan pembelajaran yang memungkinkan 
terjadinya proses pembelajaran dan tercapainya kompetensi yang ditentukan. Model pembelajaran merupakan kerangka konseptual dan operasional pembelajaran yang memiliki nama, ciri, urutan logis, pengaturan, dan budaya. Metode pembelajaran merupakan cara atau teknik yang digunakan oleh pendidik untuk menangani suatu kegiatan pembelajaran yang mencakup antara lain ceramah, tanyajawab, diskusi. Pendekatan pembelajaran menggunakan pendekatan saintifik/pendekatan berbasis proses keilmuan yakni: (a) mengamati; (b) menanya; (c) mengumpulkan informasi/mencoba; (d) menalar/mengasosiasi; dan (e) mengomunikasikan.

Untuk mewujudkan pendekatan, strategi, metode, teknik seperti yang diinginkan di atas, tidak sepenuhnya bisa terlaksana. Hal yang menjadi factor kendala antara lain: para guru belum mempunyai pegetahuan yang cukup dalam melaksanakannya; guru-guru belum terbiasa dengan inovasi-inovasi yang cenderung cepat; belum didukung dengan prasarana dan sarana yang memadai; dan hal yang tidak kalah pentingnya adalah belum ada pelatihan-pelatihan untuk menyamakan persepsi dan mengembangkan perangkat pembelajaran khususnya bagi guru-guru Sekolah Dasar di Gugus V Kecamatan Kediri, Tabanan. Berdasarkan wawancara dan diskusi yang kami lakukan dengan guru-guru Sekolah Dasar di Gugus V Kecamatan Kediri hasilnya menunjukkan bahwa dari 25 orang guru kelas, hampir semua orang guru yang menyatakan belum memahami dengan baik pengembangan perangkat pembelajaran berdasarkan kurikulum 2013.

Dalam Peraturan Menteri Pendidikan dan Kebudayaan Republik Indonesia No. 22 Tahun 2016 tentang Standar Proses Pendidikan Dasar dan Menengah disebutkan bahwa karakteristik pembelajaran pada setiap satuan pendidikan terkait erat pada Standar Kompetensi Lulusan dan Standar Isi. Standar Kompetensi Lulusan memberikan kerangka konseptual tentang sasaran pembelajaran yang harus dicapai. Standar Isi memberikan kerangka konseptual tentang kegiatan belajar dan pembelajaran yang diturunkan dari tingkat kompetensi dan ruang lingkup materi. Sesuai dengan Standar Kompetensi Lulusan, sasaran pembelajaran mencakup pengembangan ranah sikap, pengetahuan, dan keterampilan yang dielaborasi untuk setiap satuan pendidikan. Ketiga ranah kompetensi tersebut memiliki lintasan perolehan (proses psikologis) yang berbeda. Sikap diperoleh melalui aktivitas" menerima, menjalankan, menghargai, menghayati, dan mengamalkan". Pengetahuan diperoleh melalui aktivitas" mengingat, memahami, menerapkan, menganalisis, mengevaluasi, mencipta. Keterampilan diperoleh melalui aktivitas" mengamati, menanya, mencoba, menalar, menyaji, dan mencipta". Karaktersitik kompetensi beserta perbedaan lintasan perolehan turut serta mempengaruhi karakteristik standar proses. Untuk memperkuat pendekatan ilmiah (scientific), tematik terpadu (tematik antarmata pelajaran), dan tematik (dalam suatu mata pelajaran) perlu diterapkan pembelajaran berbasis penyingkapan/penelitian (discovery/inquiry learning). Untuk mendorong kemampuan peserta didik untuk menghasilkan karya kontekstual, baik individual maupun kelompok maka sangat disarankan menggunakan pendekatan pembelajaran yang menghasilkan karya berbasis pemecahan masalah(project based learning).

Perencanaan pembelajaran dirancang dalam bentuk Silabus dan Rencana Pelaksanaan Pembelajaran (RPP) yang mengacu pada Standar Isi. Perencanaan pembelajaran meliputi penyusunan rencana pelaksanaan pembelajaran dan penyiapan media dan sumber belajar, perangkat penilaian pembelajaran, dan skenario pembelajaran. Penyusunan Silabus dan RPP disesuaikan pendekatan pembelajaran yang digunakan.

Silabus merupakan acuan penyusunan kerangka pembelajaran untuk setiap bahan kajian mata pelajaran. Silabus paling sedikit memuat:
a. Identitas
mata pelajaran
(khusus
SMP/MTs/SMPLB/Paket
dan

SMA/MA/SMALB/SMK/MAK/Paket C/ Paket C Kejuruan );

b.Identitas sekolah meliputi nama satuan pendidikan dan kelas;

c. Kompetensi inti, merupakan gambaran secara kategorial mengenai kompetensi dalam aspek sikap, pengetahuan, dan keterampilan yang harus dipelajari peserta didik untuk suatu jenjang sekolah, kelas dan mata pelajaran;

d.Kompetensi dasar, merupakan kemampuan spesifik yang mencakup sikap, pengetahuan, dan keterampilan yang terkait muatan atau mata pelajaran;

e. Tema(khususSD/MI/SDLB/Paket A);

f. Materi pokok, memuat fakta, konsep, prinsip, dan prosedur yang relevan, dan ditulis dalam bentuk butir-butir sesuai dengan rumusan indikator pencapaian kompetensi;

g.Pembelajaran,yaitu kegiatan yang dilakukan oleh pendidik dan peserta didik untuk mencapai kompetensi yang diharapkan;

h.Penilaian, merupakan proses pengumpulan dan pengolahan informasi untuk menentukan pencapaian hasil belajar peserta didik;

i. Alokasi waktu sesuai dengan jumlah jam pelajaran dalam struktur kurikulum untuk satu semester atau satu tahun; dan 
j. Sumber belajar, dapat berupa buku, media cetak dan elektronik, alam sekitar atau sumber belajar lain yang relevan.

Rencana Pelaksanaan Pembelajaran (RPP) adalah rencana kegiatan pembelajaran tatap muka untuk satu pertemuan atau lebih. RPP dikembangkan dari silabus untuk mengarahkan kegiatan pembelajaran peserta didik dalam upaya mencapai Kompetensi Dasar (KD). Setiap pendidik pada satuan pendidikan berkewajiban menyusun RPP secara lengkap dan sistematis agar pembelajaran berlangsung secara interaktif, inspiratif, menyenangkan, menantang, efisien, memotivasi peserta didik untuk berpartisipasi aktif, serta memberikan ruang yang cukup bagi prakarsa, kreativitas, dan kemandirian sesuai dengan bakat, minat, dan perkembangan fisik serta psikologis peserta didik. RPP disusun berdasarkan KD atau subtema yang dilaksanakan dalam satu kali pertemuan atau lebih.

Dalam menyusun RPP hendaknya memperhatikan prinsip-prinsip sebagai berikut.

a. Perbedaan individual peserta didik antara lain kemampuan awal, tingkat intelektual, bakat, potensi, minat, motivasi belajar, kemampuan sosial, emosi, gaya belajar, kebutuhan khusus, kecepatan belajar, latar belakang budaya, norma, nilai, dan/atau lingkungan peserta didik.

b. Partisipasi aktif peserta didik.

c. Berpusat pada peserta didik untuk mendorong semangat belajar

d.Pengembangan budaya membaca dan menulisyang dirancang untuk mengembangkan kegemaran membaca, pemahaman beragam bacaan, dan berekspresi dalam berbagai bentuk tulisan.

e. Pemberian umpan balik dan tindak lanjut RPP memuat rancangan program pemberian umpan balik positif, penguatan, pengayaan, dan remedi.

f. Penekanan pada keterkaitan dan keterpaduanantara KD, materi pembelajaran, kegiatan pembelajaran, indikator pencapaian kompetensi, penilaian, dan sumber belajar dalam satu keutuhan pengalaman belajar.

g. Mengakomodasi pembelajaran tematik-terpadu, keterpaduan lintas mata pelajaran, lintas aspek belajar, dan keragaman budaya.

h.Penerapan teknologi informasi dan komunikasi secara terintegrasi, sistematis, dan efektif sesuai dengan situasi dan kondisi.

Berdasarkan analisi situasi di atas dapat dirumuskan masalah dalam P2M ini adalah "Bagaimana cara meningkatkan kemampuan guru-guru sekolah dasar di gugus $\mathrm{V}$ Kecamatan Kediri, Kabupaten Tabanan dalam mengembangkan perangkat pembelajaran berdasarkan Permendikbud nomor 22 tahun 2016?"

Tujuan kegiatan pengabdian pada masyarakat ini adalah untuk meningkatkan kemampuna guruguru sekolah dasar di gugus V Kecamatan Kediri, Kabupaten Tabanan dalam mengembangkan perangkat pembelajaran. Adapun manfaat kegiatan pengabdian pada masyarakat ini adalah sebagai berikut. 1) Bagi Guru. Melalui kegiatan pengabdian pada masyarakat ini, guru-guru sekolah dasar di gugus V Kecamatan Kediri, Kabupaten Tabanan mampu mengembangkan perangkat pembelajaran. 2) Bagi Sekolah dan Siswa Guru yang sudah mampu mengembangkan perangkat pembelajaran yang berdasrkan permendikbud nomor 22 tahun 2016 akan dapat meningkatkan layanan pada siswa dalam proses pembelajaran yang lebih baik atau berkualitas dan kemudian akan berdampak pada hasil belajar siswa yang lebih baik juga.

\section{Metode}

Kegiatan P2M ini dilaksanakan dengan mempergunakan metode ceramah dugunakan pada saat nara sumber memaparkan materi tentang pengembangan perangkat pembelajaran berdasarkan Permendikbud nomor 22 tahun 2016. Setelah itu dilanjutkan dengan tanyajawab, diskusi sampai peserta memahami materi yang telah disampaikan. Kemudian dilanjutkan dengan kegiatan pelatihan penyusunan rencana pelaksanaan pembelajaran (RPP). Berikutnya dilanjutkan dengan simulasi serta pendampingan. Hasil akhir kerja peserta yang berupa RRP diberikan nilai.

Metode pelaksanaan kegiatan P2M ini dapat digambarkan seperti bagan berikut. 


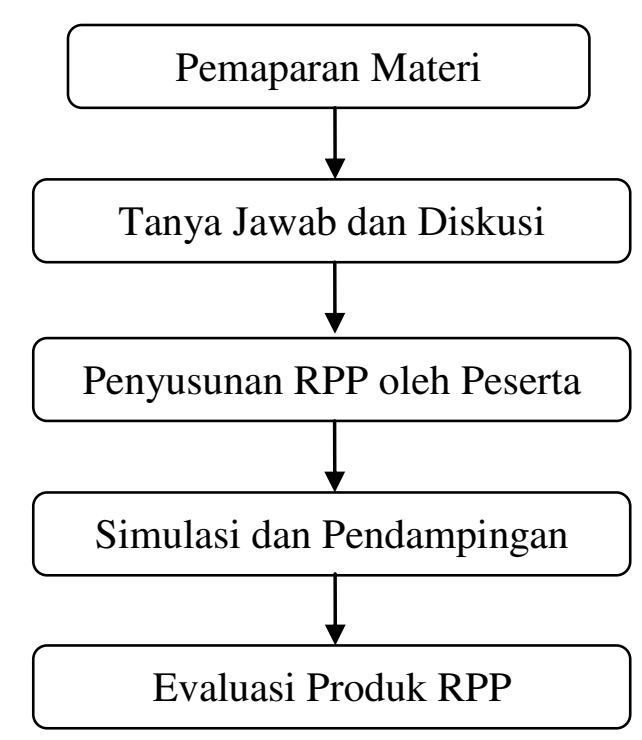

\section{Hasil dan pembahasan}

Pada saat dilakukan kegiatan penyampaian materi penyusunan Rencana Pelaksanaan Pembelajaran (RPP) dan perangkatnya, para guru dengan sangat antusias memperhatian materi yang disajikan. Hal ini dapat kita lihat ketekunan peserta mengikuti pemaparan materi dari awal sampai akhir tidak ada guru meninggalkan tempat kegiatan. Pada saat peserta diberikan kesempat untuk bertanya, kesempatan itu tidak disia-siakan oleh guru-guru untuk bertanya. Peserta mengajukan beberapa pertanyaan sebagai berikut.

1) Apakah jumlah indikator harus sama dengan jumlah tujuan pembelajaran? (Ni Wayan Periwati)

2) Apakah lembar karja siswa (LKS) harus diambil dari buku siswa yang telah disiapkan? (Ni Made Armawati)

3) Bagaimana mendapat alat atau media pembelajaran yang sangat sedikit jika dibandingan dengan jumlah siswa? (Lindawati)

4) Bagaimana cara menilai sikap spiritual dan sosial?

Pertanyaan tersebut dijawab oleh penyaji sebagai berikut.

1) Jumlah tujuam pembelajaran tidak harus sama dengan jumlah indikator. Artinya bisa sama bisa juga lebih. Oleh karena itu maka sebelum pembelajaran atau menyusun RPP didahuli dengan kegiatan analisis kurikulum atau silabus, selanjutnya dikuti analisis atau mengidentifikasi semua hal yang berkaitan dengan pencapaian indicator pembelajaran.

2) Demikian juga tetang LKS yang akan digunakan tidak harus yang sudah disiapkan pada buku, walaupun misalnya diambil dari buku tapi masih bisa dimodivikasi agar dapat menarik dan meningkatan kreativitas fisik maupun mental siswa.

3) Untuk memenuhi kebutuhan akan media atau alat-alat yang diperlukan dalam pembelajaran adalah bisa dengan membeli, bisa juga dengan membuat sendiri media atau alat-alat sederhana dengan memanfaatkan barang bekas yang tidak digunakan lagi dan mudah dicari di lingkungan, bahkan sedapat mungkin mengajak anak atau siswa terlibat langsung untuk menyiapakan bahan-bahan yang diperlukan, seperti misalnya membawa gelas aqua bekas, pipet bekas dan lain-lain.

4) Penilaian sikap spiritual, harus menggunakan format penilaian dengan aspek dan kriteria yang jelas. Pelaksanaan penilaiannya pada momen-momen tertentu dalam kurun waktu yang relatip lama. Demikian juga penilaian sikap sosial disamping aspek dan kriteriannya yang jelas, membutuhkan waktu lama dan tidak hanya dikelas, bisa pada saat anak bermain di lapangan, di halaman sekolah dan pada kegiatan kerja kelompok lainnya. Oleh karena itu tampaknya guru perlu memiliki buku catatan penilaian sikap sosial atau anecdote, lebih penting lagi guru diharapkan mengenal siswanya dengan baik sehingga guru dapat memberikan nilai yang lebih objektif.

Setelah para peserta memahami cara menyusun atau membuat RPP dan perangkatnya, maka selanjutnya peserta ditugaskan untuk membuat RRP dan perangkatnya masing-masing. Pada kegiatan pengabdian pada masyarakat di gugus Kediri dapat disamapaikan bahwa antusias dan rasa ingin tahu para guru sangat tinggi. Hal ini dapat dilihat dari perhatian dan ketekunan peserta mengikuti kegiatan dari awal sampai akhir tidak ada peserta yang meninggalkan tempat. Demikian juga hasil kerja para guru 
sangat baik dimana dari 25 orang guru kelas sebagai peserta, 24 0rang guru atau 96 persen dapat dinyatakan telah mampu menyusun RPP dan perangkatnya dengan baik sesuai dengan Permen 22 tahun 2016. Lagi 1 orang guru atau 4 persen kurang mampu terutama dalam merumuskan tujuan, dimana tujuan yang dirumuskan kurang mengaktipkan siswa dan juga lamban. Kelambanan ini dikarenakan faktor usia mereka lebih dari lima puluh tahun.

Berdasarkan keantusiasan dan ketekunan peserta pelatihan menunjukan minat dan sikap yang positip dari para peserta terhadap sesuatu yang dapat meningkatkan kemampuan dalam melaksanakan tugasnya sebagai guru. Dari hasil penilaian terhadap RPP yang dibuat oleh guru - guru sebagai peserta pelatihan sangat baik, ini berarti terjadinya peningkatan kemampuan dan keterampilan guru-guru di gugus Kediri dalam menyusun perangkat pembelajaran. Peningkatan kemampuan dan keterampilan guru dalam menyusun RPP dapat terjadi peningkatan kualitas perencanaan pembelajaran. Peningkatan kualitas itu tampaknya belum berarti apa-apa jika kalau tidak diikuti dengan peningkatan kemampuan dan keterampilan mengimplementasikannya di dalam kelas. Untuk itu tampaknya diperlukan pelatihan lanjutan tentang implementasi RPP dalam kelas.

Rencana pelaksanaan pembelajaran yang telah dikembangkan dalam pelatihan ini sesuai dengan Permendikbud nomor 22 tahun 2016 yang menekankan dalam proses pembelajaran interaksi antar peserta didik, antara peserta didik dengan pendidik, dan peserta didik dengan sumber belajar pada suatu lingkungan belajar. Dengan pola multi interaksi ini, akan tercipta situasi belajar siswa yang menyenangkan, menantang, kontetual dan kolaboratif, yang penerapannya dengan pendekatan saintifik.

Dengan kegiatan pelatihan pengembangan perangkat pembelajaran yang mengarahkan kegiatan belajar berpusat pada siswa merupakan pembelajaran yang bertujuan meningkatkan kualitas proses yang pada akhirnya akan berdampak pada peningkan kualitas hasil belajar. Terjadinya peningkatan kualitas perencanaan pembelajaran dalam bentuk RPP yang disertai perangkat lainnya itu akan meningkatkan kualitas proses dan kualitas hasil belajar siswa. Dengan demikian ini dapat dinyatakan bahwa terjadinya peningkatan kualitas perencanaan dan pelaksanaan pembelajaran akan berdampak pada peningkatan sumber daya manusia.

\section{Simpulan dan saran}

Berdasarkan hasil dan pembahasan di atas dapat disimpulkan sebagai berikut.

1) Minat dan ketekunan guru-guru di GugusV Kecamatan Kediri, Kabupaten Tabanan dalam mengikuti pelatihan pengembangan perangkat pembelajaran sangat baik.

2) Kemampuan guru-guru peserta pelatihan di Gugus V Kecamatan Kediri, Kabupaten Tabanan dalam mengembangkan perangkat pembelajaran juga sangat baik.

Berdasarkan hasil yang dicapai dalam pelatihan pengembangan perangkat pembelajaran, dapat disampaikan saran sebagai berikut.

1) Kepada guru-guru diharapkan tidak cepat merasa puas dengan hasil yang diperoleh, dan selalu lebih meningkatan kemampuan dan keterampilan dalam mengembangkan perangkat pembelajaran.

2) Kepada kepala sekolah, mendorong dan memberi kesepatan pada guru-guru untuk mengkuti setiap ada kegiatan yang sejenis dalam meningkatkan tugas profesinya.

3) Kepada para pengambil kebijakan, diharapakan lebih sering mengadakan pelatihan-pelatihan yang terkait dengan peningkatan kualitas guru..

\section{Daftar Rujukan}

Astawan, I Gede.2015. Pelatihan Penyusunan Proposal Penelitian Tindakan Kelas Berorientasi Kurikulum 20134 Bagi Guru-Guru Di SD Kabupaten Buleleng. Singaraja : Universitas Pendidikan Ganesha.

Erikson, E. (1950). Childhood and society. New York: Norton.

Kepmendikbud. 2016. Standar Proses Pendidikan Dasar dan Menengah:Jakarta.Depdikbud

Piaget, J. (1932). The moral judgment of the child. London: Routledge \& Kegan Paul.

Sri Anitah, dkk. 2008. Strategi Pembelajaran di SD. Jakarta: Universitas Terbuka

Sekolah Dasar net. 2008. Konsep Dasar Pembelajaran Terpadu di Sekolah Dasar. http://www.sekolahdasar.net/2009/10/konsep-dasar-pembelajaran-terpadu-di.html

Udin S. Winataputra, 2007. Teori Belajar dan Pembelajaran. Jakarta: Universitas Terbuka 